\title{
Effect of autoclave devitalization on autograft incorporation and bone morphogenetic protein of tibia in Sprague-Dawley rats
}

\author{
Anak A.G.Y. Asmara, ${ }^{1}$ Achmad F. Kamal, ${ }^{1}$ Nurjati C. Siregar, ${ }^{2}$ Marcel Prasetyo ${ }^{3}$ \\ ${ }^{1}$ Department of Orthopaedic and Traumatology, Faculty of Medicine, Universitas Indonesia, Cipto Mangunkusumo Hospital, Jakarta, \\ Indonesia \\ ${ }^{2}$ Department of Pathology Anatomy, Faculty of Medicine, Universitas Indonesia, Cipto Mangunkusumo Hospital, Jakarta, Indonesia \\ ${ }^{3}$ Department of Radiology, Faculty of Medicine, Universitas Indonesia, Cipto Mangunkusumo Hospital, Jakarta, Indonesia
}

\begin{abstract}
Abstrak
Latar belakang: Pemanasan autoklaf merupakan salah satu modalitas limb salvage yang banyak digunakan, namun hasilnya tidak memuaskan karena dapat mengurangi kekuatan mekanik tulang. Namun mengingat modalitas ini dapat diterima masyarakat dari segi keuangan, agama, budaya dan sosiokultural, maka dilakukan penelitian pada tikus yang diberikan perlakuan reseksi dan rekonstruksi dengan metode autoklaf. Proses penyembuhan tulang dinilai dari gambaran sekuensial radiologis, gambaran histopatologis, hitung osteoblas serta bone morphogenic protein (BMP).
\end{abstract}

Metode: 36 ekor tikus Sprague-Dawley dilakukan operasi reseksi tulang en bloc sepanjang $7 \mathrm{~mm}$. Tikus kemudian dibagi ke dalam 2 kelompok: 1 kelompok autoklaf dilakukan pemanasan dengan autoklaf pada suhu $134^{\circ} \mathrm{C}$ selama 15 menit; dan 1 kelompok kontrol yang tidak menjalani autoklaf. Autograft kemudian difiksasi dengan $\mathrm{k}$-wire. Pemeriksaan radiologis dilakukan pada minggu ke-5 dan ke-8 untuk menentukan skor radiologis menurut Lane dan Sandhu. Pada minggu ke-8, tikus dikorbankan untuk pemeriksaan histopatologis (skor histologis menurut modifikasi Salkeld), hitung osteoblas, dan ekspresi BMP-2.

Hasil: Terdapat perbedaan bermakna antara kelompok kontrol dan autoklaf pada skor radiologis di minggu ke-5 $(5,12 \pm 1,6 \mathrm{~g}$ vs 3,21 $\pm 2,42, p=0,023)$ dan ke-8 (6,06 $\pm 1,71$ vs 4,29 $\pm 2,53, p=0,040)$, skor histologis $(6,06 \pm$ $1,14$ vs 4,14 $\pm 1,99, p=0,005)$, osteoblas $(p<0,001)$ dan ekspresi BMP-2.

Kesimpulan: Autoklaf menyebabkan inkorporasi graft terjadi lebih lambat sehingga menurunkan kualitas penyembuhan tulang. Oleh karena itu penggunaan autoklaf sebagai alat pengolahan ulang bone graft pada pembedahan limb salvage tidak dianjurkan.

\begin{abstract}
Background: Heating process with autoclave is one of limb salvage modalities that are widely used. but the results are not satisfying, due to mechanical bone fragility. However, considering this treatment modality is widely accepted in terms of financial, religion and sociocultural aspects, we conducted a on study rats treated with resection and reconstruction with autoclave heating method to assess bone healing by sequential radiology, histopathologic osteoblasts count, and bone morphogenetic protein (BMP).
\end{abstract}

Methods: Thirty six Sprague-Dawley rats were divided into two groups with one group being the autoclave group and others served as control group. In both groups, the tibial diaphysis was extracted en bloc for $7 \mathrm{~mm}$. All groups were kept for 8 weeks and treated under the same condition except the autoclave group, where the extracted bones were put into autoclave at $134^{\circ} \mathrm{C}$ for 15 minutes and refixed again with $\mathrm{k}$-wire. We performed radiological examination at $5^{\text {th }}$ and $8^{\text {th }}$ week using Lane and Sandhu radiological score. After extraction, the tibial bones were inspected for histological pattern using Salked modified score, osteoblast quantity counting and BMP-2 values.

Results: There were statistically significant diffences between control and autoclave group on radiological score at $5^{\text {th }}(5.12 \pm 1.6 \mathrm{~g}$ vs $3.21 \pm 2.42, \mathrm{p}=0.023)$ and $8^{\text {th }}$ week $(6.06 \pm 1.71$ vs $4.29 \pm 2.53, p=0.040)$, histological score between groups $(6.06 \pm 1.14$ vs $4.14 \pm 1.99, p=0.005)$, osteoblast count $(\mathrm{p}<0.001)$, and BMP-2 expression, respectively.

Conclusion: Autoclave recycling autograft lowered the speed of graft incorporation and BMP-2 expression. Therefore, autoclave recycling autograft as a method of limb salvage surgery must be reevaluated and not considered to be applied for treatment in bone malignancy.

Keywords: autoclave, BMP-2, graft incorporation, osteoblast

pISSN: 0853-1773• eISSN: 2252-8083 • http://dx.doi.org/10.13181/mji.v23i2.992 • Med J Indones. 2014;23:74-8

Correspondence author: Anak A.G.Y. Asmara, yudaasmara17@yahoo.com

Copyright @ 2014 Authors. This is an open access article distributed under the terms of the Creative Commons Attribution-NonCommercial-ShareAlike 4.0 International License (http://creativecommons.org/licenses/by-nc-sa/4.0/), which permits unrestricted non-commercial use, distribution, and reproduction in any medium, provided the original author and source are properly cited. 
Advancements in diagnostic imaging, neoadjuvant chemotherapy, and surgical technique have now enabled limb salvage procedure in the management of bone and soft tissue sarcoma. Limb salvage surgery preserves function and vitality of the extremity without devastating the survival rate. ${ }^{1-3}$ This surgery includes usage of endoprosthesis, osteoarticular allograft, endoprosthetic composite, vascularized bone graft, rotationplasty, expendable endoprothesis, or extracorporeal irradiation (ECI). ${ }^{1-3}$

Many limb salvage techniques with megaprostesis are limited in Indonesia. Endoprothesis is costly. Allograft is associated with high immunological response and hardly available. It is also conferred with socioreligional beliefs that prohibit usage of others' organ. ${ }^{1-3}$

Therefore recycling autograft is more suitable in Indonesia. Many methods have been developed for en bloc resection followed by autoclave, pasteurization, and irradiation. Autoclave benefits in cost and low immunological response. However, some have reported autoclave to lower osteoinductivity of the bone that might result in nonunion and infection. ${ }^{4}$

We conducted this study to evaluate the effect of autoclave on healing properties of bone based on sequential radiography, osteoblast count, and expression of bone morphogenetic protein (BMP).

\section{METHODS}

We conducted this research between December 2010 until April 2011. Thirty six Spraque-Dawley rats were divided into two groups. Both groups were kept in under the same situation for eight weeks. First group had undergone autoclave heating $\left(134^{\circ} \mathrm{C}\right.$ for 15 minutes) process on extracted bone, and the second group served as a control group (without autoclave treatment). In both groups, tibial diaphysis was extracted en bloc for 7 milimetres and refixed again with $\mathrm{K}$-wires. We performed radiological examination at the $5^{\text {th }}$ and $8^{\text {th }}$ week and assessed the proximal and distal osteotomy line with Lane and Sandhu radiological score (Table 1). The maximal score of healing is 8 (sum of maximal score for the proximal and distal side). All mice were harvested at $8^{\text {th }}$ week. After extraction, the tibial bones were inspected for histological pattern with Salkeld modified score (Table 2), the maximal score of healing is 8 (sum of maximal score for the proximal side and distal side). Osteoblast count and BMP-2 values were also investigated.
Table 1. Lane and Sandhu radiological score*

\begin{tabular}{lc}
\hline Criteria & Score \\
\hline No healing & 0 \\
Callus formation & 1 \\
Bone formation & 2 \\
Loss of osteotomy line & 3 \\
Complete union & 4 \\
\hline
\end{tabular}

${ }^{*}$ Data are from Lane, et al. ${ }^{5}$

Table 2. Modified Salkeld score*

\begin{tabular}{lc}
\hline Healing quality & Score \\
\hline No healing & 0 \\
\hline Healing with & 1 \\
\hline Fibrosis & 2 \\
\hline Fibrocartilage or cartilage & 3 \\
\hline Mineralized cartilage & 4 \\
\hline Mature bone & \\
\hline
\end{tabular}

*Data are from Salkeld, et al. ${ }^{6}$

BMP-2 expression was divided into three scores. Score +1 : less than $1 / 3$ positive staining cell of BMP2 expression. Score $+2: 1 / 3-2 / 3$ positive staining cell. Score +3 : more than $2 / 3$ positive staining cell. Evaluation of osteoblast count was considered negative (-) if we did not find any osteoblast, $(+1)$ if osteoblast was present, but not in all microscopic field, $(+2)$ if osteoblast was present in all microscop field.

\section{RESULTS}

No significant difference of weight was found between groups at the commence of the study. Five samples were excluded due to pull out of the wire. Radiological scores at $5^{\text {th }}$ week were $5.12 \pm 1.69$ and $3.21 \pm 2.42(\mathrm{p}=0.023)$ and at $8^{\text {th }}$ week were $6.06 \pm$ 1.71 and $4.29 \pm 2.53(\mathrm{p}=0.040)$ for control group and autoclave group respectively. The radiological images from control and autoclave group at $5^{\text {th }}$ and $8^{\text {th }}$ week are depicted in figure 1 and 2 . There was significant difference in histological score between groups $(6.06 \pm 1.14$ vs. $4.14 \pm 1.99, p=0.005$ for control and autoclave groups). Osteoblast count also differed significantly $(\mathrm{p}<0.001)$ between groups. All subjects in control group had osteoblast score of +2 while only $42.9 \%$ in autoclave group had score of +2 (Table 3). Comparation of BMP-2 score examination

Tabel 3. Comparison of osteoblast count between two groups

\begin{tabular}{lccc}
\hline & \multicolumn{2}{c}{ Osteoblast count } & \\
\cline { 2 - 3 } \multicolumn{1}{c}{ Group } & +1 & +2 & $\mathrm{p}$ \\
\hline Control & $\mathrm{n}(\%)$ & $\mathrm{n}(\%)$ & $<0.001$ \\
Autoclave & $0(0)$ & $17(100)$ & $<0.001$ \\
\hline
\end{tabular}


showed that, $70.6 \%$ of control group scored +2 and $29.4 \%$ scored +3 , while $71.4 \%$ and $28.6 \%$ of subjects in autoclave group scored +1 and +2 respectively (Table 4). The microscopic images of osteoblast count and BMP-2 expression are shown in figure 3 and 4.

\section{DISCUSSION}

The radiological examination at $5^{\text {th }}$ and $8^{\text {th }}$ week
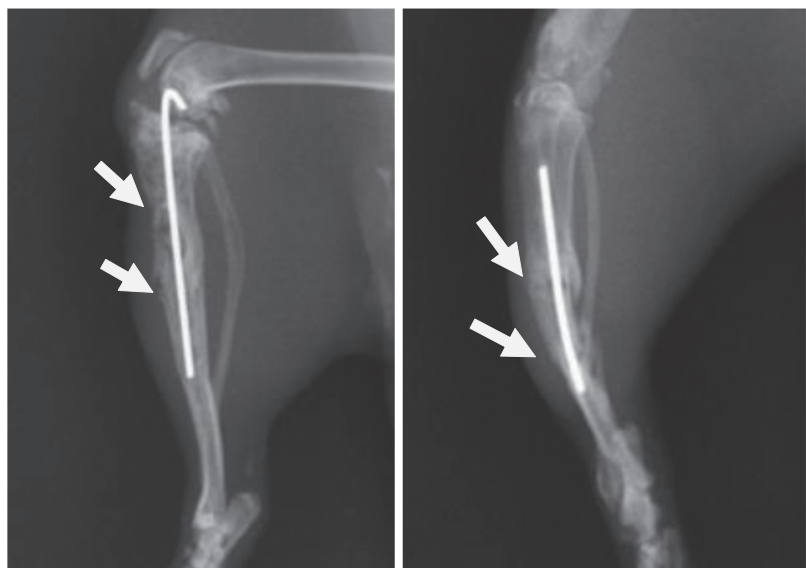

Figure 1. Radiological evaluation at $5^{\text {th }}$ week. In control group (left), complete union already occurred with remodelling of the intramedullary canal (score 7) while in autoclave group (right), osteotomy line (show in arrow) was still seen at the proximal area (score 5)
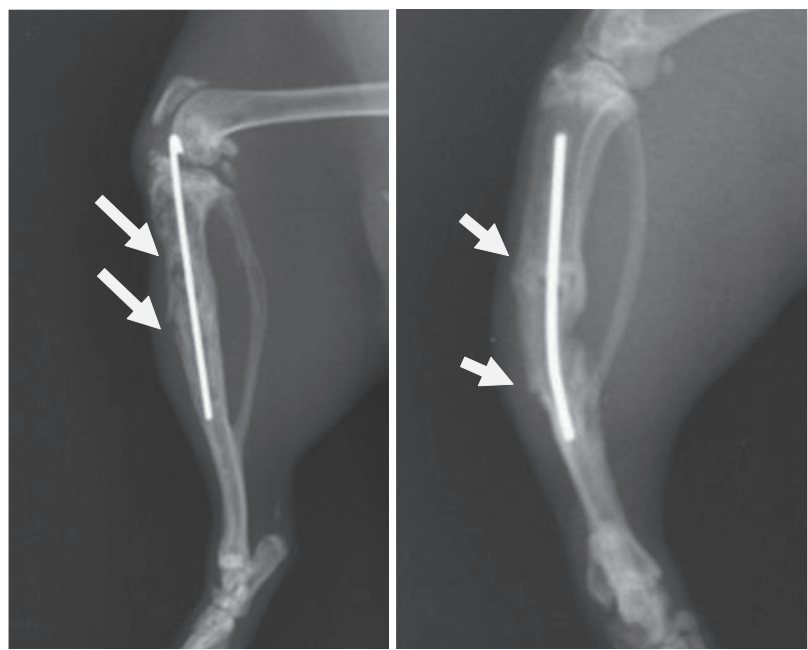

Figure 2. Radiological evaluation at $8^{\text {th }}$ week. Control group (left) showed complete bone formation with remodelling of intramedullary canal (score 8 ) while in autoclave group (right), the osteotomy line was still seen (score 6) revealed that, the autograft group failed to achieve the consolidation phase. Union of the fracture was limited to callus formation. On the other hand, control group achieved complete union with remodelling of the bone.

Kohler reported a negative effect of autoclave to bone. Collagen will denature into gelatin at temperature above $70^{\circ} \mathrm{C} .{ }^{1}$ Rauch reported that BMP-2 expression can be detected by immunohistochemical examination with BMP2 reagen (p275) pAb. ${ }^{7}$ Manabe compared limb salvage, autoclave, pasteurization, and normal bone and found that autoclave resulted in resorption of the bone followed with minimal bone formation. ${ }^{8}$ Mineral degeneration in autoclave
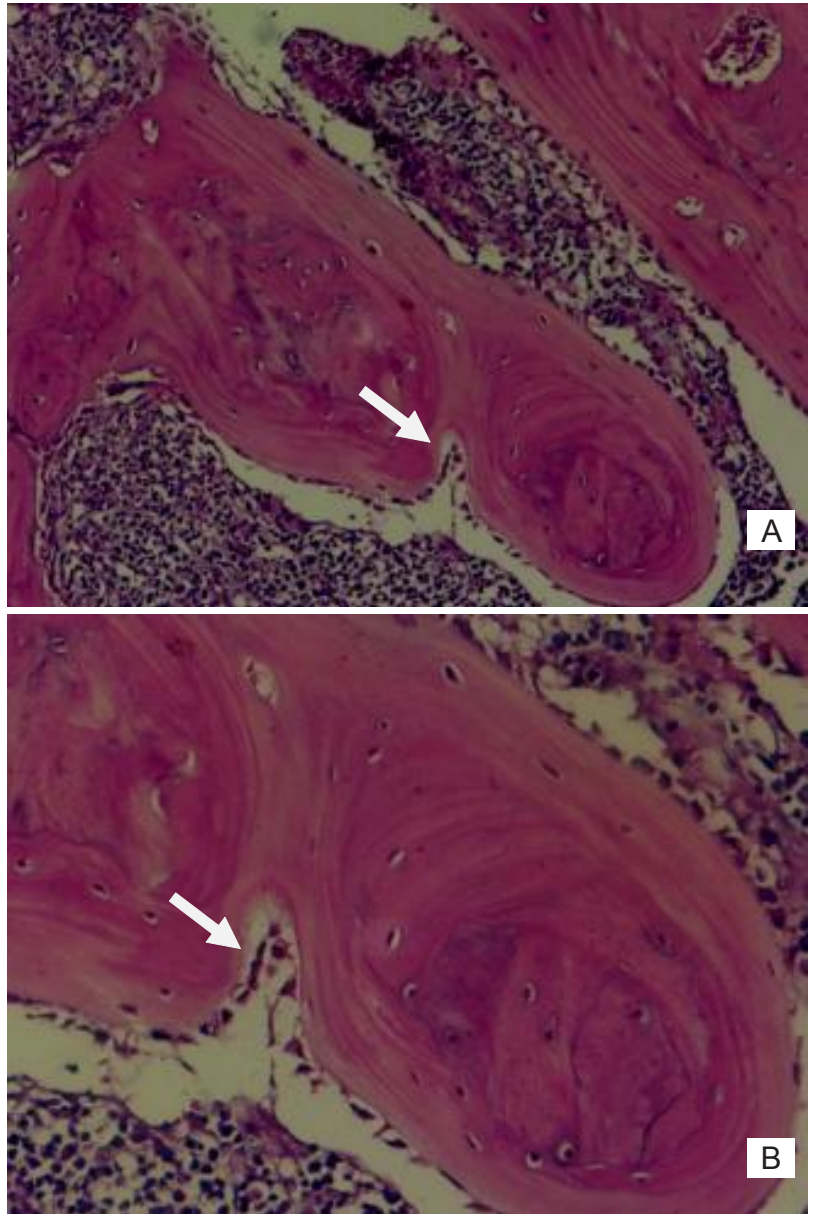

Figure 3. Picture of osteoblast count score of +2 (H-E staining) with 20x magnification (A) and 40x magnification (B)

Tabel 4. Comparison of BMP-2 expression score between two groups

\begin{tabular}{lcccc}
\hline & \multicolumn{3}{c}{ BMP-2 expression score } & \\
\cline { 2 - 4 } \multicolumn{1}{c}{ Group } & +1 & +2 & +3 & $\mathrm{p}$ \\
& $\mathrm{n}(\%)$ & $\mathrm{n}(\%)$ & $\mathrm{n}(\%)$ & $<0.001$ \\
Control & $0(0.0)$ & $12(70.6)$ & $5(29.4)$ & $<0.001$ \\
Autoclave & $10(71.4)$ & $4(28.6)$ & $0(0.0)$ & \\
\hline
\end{tabular}



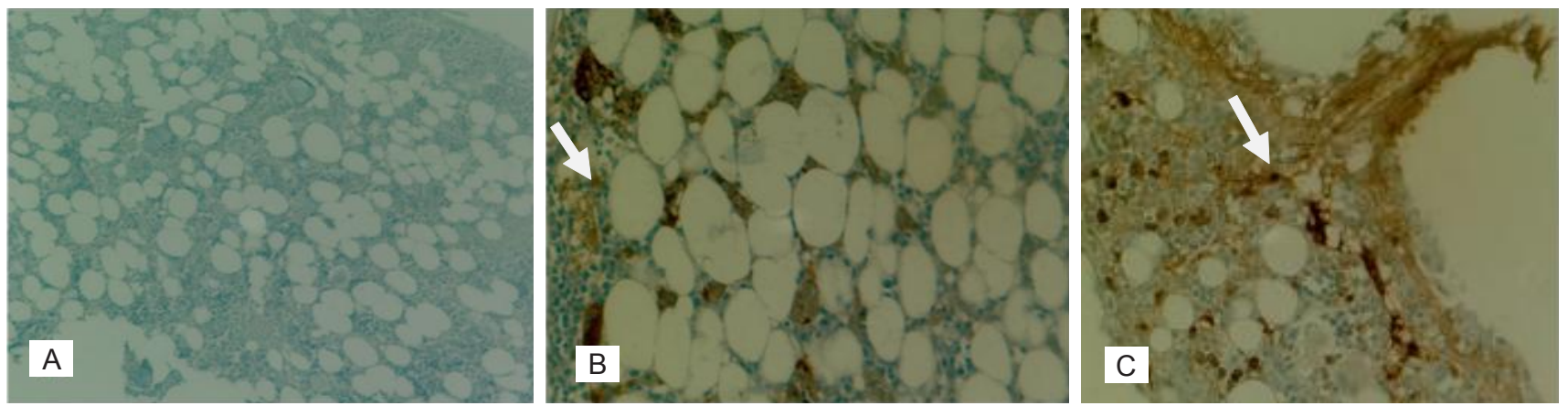

Figure 4. Expression of BMP-2 with immunohistochemistry examination (40x magnification). (A) No positive staining (negative score) used as a negative control. (B) BMP-2 expression with value of less than $1 / 3$ positive staining cell (+1). (C) BMP-2 expression with values between $1 / 3-2 / 3$ positive staining cell $(+2)$

bone also occurred in exceeding rate compared to pasteurization. Pasteurization did not result in bone structural damage. ${ }^{9}$ In recent study by Vural, autoclave was found to differ insignificantly to pasteurization in terms of quality of bony union both histologically and radiologically. However, the histological score was better in pasteurization group. ${ }^{9}$ Zoricic found better osteoinductive potency in pasteurization group compared to autoclave group, because it proposed a growth factor sparing responsible for osteoinduction. ${ }^{10}$

This study showed that autoclave result in lower osteoblast count. Similar results have been reported by Salter, ${ }^{11}$ Dimitriou, ${ }^{12}$ and Brinker. ${ }^{13}$ We also demonstrated that autoclave lowered BMP-2 activity. BMP is active polypeptide which stimulates pluripotent mesenchymal stem cells to proliferate into osteoblasts. Ohta reported the effect of heating on BMP-2 activity and found that temperature above $90^{\circ} \mathrm{C}$ lowered biological activity while temperature above $120^{\circ} \mathrm{C}$ would eventually inactivate BMP-2. ${ }^{14}$ Vangsnes ${ }^{15}$ reported collagen structural change at temperature above $80^{\circ} \mathrm{C}$ and Urist ${ }^{16}$ reported collagen degeneration at temperature above $100^{\circ} \mathrm{C}$. Autoclave also resulted in vascular ischemic which will influence osteoinductive and osteogenesis capacities.

Lower level of BMP-2 will result in decreased osteoblast formation which in turn will affect osteoinductive and osteogenesis capacities.

In conclusion, we have demonstrated that autoclave lower osteoinductive capacity and inhibit graft incorporation based on radiological and histological healing score, osteoblast count, and expression of BMP-2. Therefore, we do not suggest the use of autoclave as a recycling method of bone graft in limb salvage surgery. Other methods such as ECI or pasteurization might be a better option for treatment modality.

\section{Conflict of interest}

The authors hereby affirm that there is no conflict of interest in this study.

\section{REFERENCES}

1. Lewis VO. What's new in musculoskeletal oncology. J Bone Joint Surg Am. 2007;89(6):1399-1407.

2. Unni KK. Osteosarcoma. In: Dahlin's bone tumors - general aspects and data on 11,087 cases. 5th ed. Philadelphia: Lippincott-Raven; 1996. p. 143-83.

3. Raymond AK, Ayala AG, Knuutila S. Conventional Osteosarcoma. In: Fletcher CDM, Unni KK, Mertens F, editors. World Health Organization Classification of Tumours. Pathology and genetics of tumours of soft tissue and bone. Lyon: IARC Press; 2002. p. 264-70.

4. Köhler P, Glas JE, Larsson S, Kreicbergs A. Incorporation of nonviable bone grafts. Autoclaved autogeneic and frozen allogeneic bone grafts compared in the rabbit. Acta Orthop Scand. 1987;58(1):54-60.

5. Lane JM, Sandhu HS. Current approaches to experimental bone grafting. Orthop Clin North Am. 1987;18(2):213-25

6. Salkeld SL, Patron LP, Barrack RL, Cook SD. The effect of osteogenic protein-1 on the healing of segmental bone defects treated with autograft or allograft bone. J Bone Joint Surg Am. 2001;83-A(6):803-16.

7. Rauch F, Lauzier D, Croteau S, Travers R, Glorieux FH, Hamdy R. Temporal and spatial expression of bone morphogenetic protein-2, -4 , and -7 during distraction osteogenesis in rabbits. Bone. 2000;27(3):453-9.

8. Manabe J. Experimental studies on pasteurized autogenous bone graft. Nippon Seikeigeka Gakkai Zasshi. 1993;67(4):255-66. Japanese.

9. Vural R, Akesen B, Karakayalı M, Yalçınkaya U, Aydınlı U. The comparison of the negative effect of autoclaving and pasteurization on bone healing. Acta Orthop Traumatol Turc. 2010;44(4):322-7.

10. Zoricic S, Bobinac D, Lah B, Maric I, Cvijanovic O, Bajek $\mathrm{S}$, et al. Study of the healing process after transplantation 
of pasteurized bone grafts in rabbits. Acta Med Okayama. 2002;56(3):121-8.

11. Salter RB. Neoplasms of musculosketal tissues. In: Textbook of disorders and injuries of the musculoskeletal system. 3rd ed. Philadelphia: Lippincott Williams \& Wilkins; 1999. p. 379-92.

12. Dimitriou R, Tsiridis E, Giannoudis PV. Current concepts of molecular aspects of bone healing. Injury. 2005;36(12):1392404.

13. Brinker MR, O'Connor DP. Basic Sciences. In: Miller MD, editor. Review of Orthopaedics. 5th ed. Philadelphia: Saunders; 2008. p. 1-36.
14. Ohta H, Wakitani S, Tensho K, Horiuchi H, Wakabayashi S, Saito N, et al. The effects of heat on the biological activity of recombinant human bone morphogenetic protein-2. J Bone Miner Metab. 2005;23(6):420-5.

15. Vangsness CT Jr, Mitchell W 3rd, Nimni M, Erlich M, Saadat V, Schmotzer H.. Collagen shortening. An experimental approach with heat. Clin Orthop Relat Res. 1997;337:267-71.

16. Urist MR, Silverman BF, Buring K, Dubuc FL, Rosenberg JM. The bone induction principle. Clin Orthop Relat Res. 1967, 53:243-83. 